\title{
Erratum to: A new species of Pomacentrus (Actinopterygii: Pomacentridae) from Micronesia, with comments on its phylogenetic relationship
}

Shang-Yin Vanson Liu ${ }^{1,2^{*}}$, Hsuan-Ching Hans $\mathrm{Ho}^{3}$ and Chang-Feng Dai ${ }^{1}$

\section{Correction}

After the publication of this article (Liu et al. 2013) it came to our attention that we had missed out the LSID code to describe new taxa. The relevant code is: urn:lsid:zoobank. org:pub:5BF08DDD-3D01-4FAF-9847-404CDB0BFEBB.

\begin{abstract}
Author details
'Institute of Oceanography, National Taiwan University, Taipei 10617, Taiwan. ${ }^{2}$ Department of Ecology and Evolutionary Biology, University of California Los Angeles, 610 Charles E. Young Drive South, Los Angeles, CA 90095, USA. ${ }^{3}$ National Museum of Marine Biology and Aquarium, Institute of Marine Biodiversity and Evolutional Biology, National Dong Hwa University, Pingtung 944, Taiwan.
\end{abstract}

Received: 20 June 2014 Accepted: 20 June 2014

Published online: 17 September 2014

\section{Reference}

Liu, et al. (2013) A new species of Pomacentrus (Actinopterygii: Pomacentridae) from Micronesia, with comments on its phylogenetic relationships. Zool Stud 52:6

\footnotetext{
* Correspondence: oceandiver6426@gmail.com

'Institute of Oceanography, National Taiwan University, Taipei 10617, Taiwan ${ }^{2}$ Department of Ecology and Evolutionary Biology, University of California Los Angeles, 610 Charles E. Young Drive South, Los Angeles, CA 90095, USA Full list of author information is available at the end of the article
}

Submit your manuscript to a SpringerOpen ${ }^{\circ}$ journal and benefit from:

- Convenient online submission

- Rigorous peer review

- Immediate publication on acceptance

- Open access: articles freely available online

- High visibility within the field

- Retaining the copyright to your article

Submit your next manuscript at springeropen.com 